НАУКОВИЙ ВІСНИК

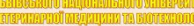
2. $3 \sin ^{4}$ 211MIIMIII

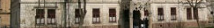
свия: ХАрчов технологі ERIIS: FOOD TE
Науковий вісник Дьвівського національного університету ветеринарної медицини та біотехнодогій імені С.3. Гжицького. Серія: Харчові технологіі

Scientific Messenger of Lviv National University of Veterinary Medicine and Biotechnologies.

Series: Food Technologies

ISSN 2519-268X print ISSN $2707-5885$ online doi: 10.32718/nvlvet-f9405

https://nvlvet.com.ua/index.php/food

UDC 637.03

\title{
Expanding the range of processed cheeses using sunflower isolate
}

\author{
N. V. Bolgova, M. M. Samilyk, V. R. Kohan, N. M. Lisova \\ Sumy National Agrarian University, Sumy, Ukraine
}

Article info

Received 02.09.2020 Received in revised form 01.10 .2020

Accepted 02.10.2020

Sumy National Agrarian University, G.Kondratieva Str., 160, Sumy, 40021, Ukraine.

Tel.: +38-097-291-88-71

E-mail: bolgova_1981@i.ua

Bolgova, N. V., Samilyk, M. M., Kohan, V. R., \& Lisova, N. M. (2020). Expanding the range of processed cheeses using sunflower isolate. Scientific Messenger of Lviv National University of Veterinary Medicine and Biotechnologies. Series: Food Technologies, 22(94), 23-26. doi: $10.32718 /$ nvlvet-f9405

The paper presents an analysis of the literature on the expansion of the range of processed cheeses using sunflower isolate. Four samples of processed cheese with different percentage of sunflower isolate were selected for the study: control, 1st $-3 \%, 2$ nd $-5 \%$ and $3 r d-7 \%$. Analyzing the results of organoleptic evaluation, it should be noted that the organoleptic characteristics of the control and the first samples were evaluated in the same number of points. Samples two and three as a result of tasting evaluation for taste lost to the first two by 0.2 and 0.4 points, respectively. The odor of the third sample with a percentage of sunflower isolate of $5 \%$ was not inferior to the first sample and was estimated at 0.1 and 0.2 points higher than the control and third samples, respectively. The increase in the percentage of sunflower isolate led to a deterioration in the taste of the developed samples. Therefore, the introduction into the recipe of processed cheese sunflower isolate in the amount of $3 \%$ allowed to obtain, according to the results of organoleptic evaluation, higher results compared to other samples. The results of studies of structural and mechanical parameters of the developed samples of processed cheese with sunflower isolate suggest that the introduction of a herbal additive in the recipe increased the structural and mechanical properties. An increase in the penetration force indicates a thickening of the consistency. Compared to the control sample, this figure increased by $1.8 \mathrm{kN} / \mathrm{m} 2$. The elastic index, which characterizes the elasticity of the cheese mass of the control sample, was lower than the first by $0.6 \mathrm{kN} / \mathrm{m} 2$. The obtained results allow us to conclude that the introduction of sunflower isolate into the formulation leads to minor structural changes within the regulatory documentation. The study found that the control sample contained $11.36 \%$ protein, and sample $1-11.55 \%$. It should be noted that the protein content has not changed significantly. Taking into account the results of the described studies, we note that the developed processed cheese with $3 \%$ sunflower isolate meets the requirements of regulatory documentation for organoleptic and structuralmechanical parameters. The structural and mechanical characteristics of the first sample indicate that the introduction of a herbal additive into the formulation has a positive effect on penetration efforts and elasticity. However, the introduction of three percent sunflower isolate did not affect the protein content of the product. protein.

Key words: processed cheese, sunflower isolate, organoleptic evaluation, penetration effort, elasticity,

\section{Розширення асортименту плавлених сирів з використанням соняшникового ізоляту}

Н. В. Болгова, М. М. Самілик, В. Р. Коган, Н. М. Лісова

Сумський національний агарний університет, м. Суми, Україна

У роботі представлено аналіз літературних джерел щзодо питання розширення асортименту плавлених сирів з використанням соняшникового ізоляту. Для дослідження обрано чотири зразки плавленого сиру з різним відсотком соняшникового ізоляту:

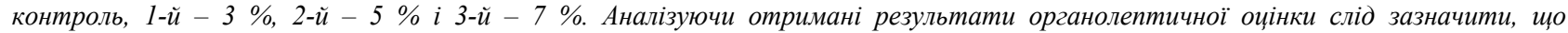
органолептичні показники контрольного та периого зразків були оцінені в однакову кількість балів. Зразки два та три в 
результаті дегустаційної оцінки за смаком поступилися периим двом на 0,2 та 0,4 бали відповідно. Запах третього зразка із відсотком соняшникового ізоляту 5 \% не поступався першому зразку та був очінений на 0,1 та 0,2 бали вище ніж у контрольного й третього зразків відповідно. Збільшення відсотку соняшникового ізоляту призвело до погіршення смаку розроблених зразків. Отже, введення у рецептуру плавленого сиру сонямникового ізоляту у кількості 3 \% дозволило отримати, за результатами органолептичної оцінки, більш високі результати порівняно з іншими зразками. Результати досліджень структурно-механічних показників розроблених зразків плавленого сиру з соняшниковим ізолятом дозволяють стверджувати, шьо введення у рецептуру рослинної добавки підвищили структурно-механічні властивості. Збільшення показника зусилля пенетрації свідчить про ущільнення консистенції. Відносно контрольного зразка цеей показник збільшився на $1,8 \mathrm{kN} / \mathrm{m2}$. Показник пружності, який характеризує еластичність сирної маси контрольного зразка, був нижчий ніж першого на 0,6 kN/m2. Отримані результати дозволяють зробити висновок, щзо введення у рецептуру соняшникового ізоляту веде до незначних структурних змін в межах нормативної документації. В ході дослідження встановили, щчо контрольний зразок містить 11,36 \% білку, а зразок 1 - $11,55 \%$. Слід зазначити, щуо суттєво вміст білку не змінився. Враховуючи результати описаних досліджень зауважимо, щзо розроблений плавлений сир з 3 \% соняшникового ізоляту відповідає вимогам нормативної документації за органолептичними та структурномеханічними показниками. Структурно-механічні харатеритики першого зразку вказують на те, щуо введення у рецептуру рослинної добавки позитивно впливає на зусилля пенетрації та пружність. Однак, введення трьох відсотків сонящникового ізоляту не вплинули на вміст у продукті білку.

Ключові слова: плавлений сир, соняшниковий ізолят, органолептична очінка, зусилля пенетрацї, пружність, білок.

\section{Вступ}

Основою здорового харчування люди вважаються продукти, які призначені для всіх вікових груп, характеризуються певним смаком та мають функціональне направлення.

Зважаючи на те, що споживачі більш свідомо ставляться до вибору продуктів харчування, споживання оброблених продуктів постійно знижується. Бажання збільшити попит на такі продукти призвело до появи широкого асортименту збагачених продуктів харчування, в тому числі і плавлених сирів (Talbot-Walsh et al., 2018; Bolhova \& Krevsun, 2019). Вони, як правило, значно доступніші ніж натуральні, мають тривалий строк зберігання та широкий асортимент. Особливий інтерес до цієї групи продуктів викликаний ще й тим, що їх можна виробляти по індивідуальному замовленню із бажаною функціональністю (Carić \& Kaláb, 1993).

M. M. El-Sayed в своїй роботі встановив, що зміна хімічного складу плавлених сирів, що містять різний відсоток ізолятів рослинного білка $(5,10$ і $15 \%)$, відбулася лише за вмістом загального азоту. Інші складові, такі як загальний вміст сухих речовин, жир і сіль, не змінилися. Органолептична оцінка розробленого плавленого сиру показала, що загальний бал поступово знижується зі збільшенням рівня ізоляту рослинного білка до 15 \%. Зменшення загальної оцінки стосується смаку, але не кольору і консистенції (El-Sayed, 2006). Схожі результати були отримані при виробництві плавленого сиру з соєвим протеїном та борошном нуту. Продукт показав прекрасну консистенцію і високий вміст білка (El-Neshawy et al., 1988). Awad R. A. та інші досліджували як вплине різний відсоток пасти люпину на технологічні показники плавленого сиру. Встановлено, що рослинна добавка в кількості до 50 \% збільшувала вміст золи і білка, в той час як плавкість знижувалася (Awad et al., 2014).

Аналіз літературних джерел показав, що сьогодні ефективними $\epsilon$ технологічні процеси виробництва продуктів харчування 3 використанням рослинної білкововмісної сировини. Здебільшого рослинні білки отримують із зерна гороху, кукурудзи, пшениці, сої та картоплі. Між собою вони відрізняються за кількістю білка, вмістом незамінних амінокислот та функціона- льними властивостями. Нестачу білка в раціоні вважають не лише економічною, а й соціальною проблемою.

Особливу увагу слід звернути на поширену в Україні культуру - соняшник (González-Pérez \& Vereijken, 2007; Shchekoldina \& Aider, 2012; Pedroche, 2015; Alexandrino et al., 2017; Ivanova et al., 2017). Основний продукт, який отримує промисловість від насіння соняшника - олія. В результаті цього технологічного процесу близько 36 \% від загальної переробленої маси насіння становить шрот. Альтернативна переробка шроту вирішує не лише проблему утилізації відходів олійного виробництва, а й проблему подолання дефіциту білку. Відомо, що білки ядра соняшникового насіння містять усі незамінні амінокислоти. За їх вмістом білок соняшника перевищує не лише насіння багатьох сільськогосподарських культур, а й коров'яче молоко. Результати досліджень показали, що ізоляти білка соняшника містять менше лізину, однак рівень інших амінокислот відповідає вимогам ФАО. Функціональні властивості білкового ізоляту соняшника були кращими або на рівні з такими ж ізолятами соєвих білків (Ren et al., 2012). Білковий ізолят, який отримують шляхом глибокої переробки насіння соняшника містить до $90 \%$ білка (Salgado et al., 2011; Dabbour et al., 2018).

Метою досліджень було розширення асортименту плавлених сирів $з$ додаванням соняшникового ізоляту. Для реалізації поставленої мети необхідно розв'язати наступі завдання: обгрунтувати оптимальну кількість білкововмісної рослинної сировини, дослідити органолептичні та структурно-механічні показники розроблених плавлених сирів.

\section{Матеріал і методи досліджень}

Матеріалами дослідження були: плавлений сир та плавлений сир з соняшниковим ізолятом. Під час виконання роботи використані стандартні, загальноприйняті методи досліджень. Органолептичні показники досліджуваних зразків оцінювали по 5-бальній шкалі. Визначення вмісту азоту проводили за ДСТУ (DSTU 5038:2008, 2009), реологічні показники на пенетрометрі “Labor" та еластопластометрі Толстого (Horalchuk, 2006). 
Для дослідження обрано чотири зразки плавленого сиру з різним відсотком соняшникового ізоляту: контроль, 1-й - 3 \%, 2-й - 5 \% і 3-й - 7 \%. Спосіб виробництва плавленого сиру з соняшниковим ізолятом передбачає: підготовку рецептурних компонентів (сир кисломолочний жирністю 9\% подрібнюємо, вершкове масло жирністю 73 \% підтоплюємо), внесення натрію двовуглекислого, харчової солі, меланжу та води, перемішування одержаної сирної маси, ії плавлення, фасування, охолодження до $\mathrm{t}=4 \pm 2{ }^{\circ} \mathrm{C}$. Соняшниковий ізолят вносили у суміш при температурі $80-85^{\circ} \mathrm{C}$ за 5-7 хв до закінчення плавлення.

\section{Результати та їх обговорення}

Важливим етапом у визначенні оптимальної кількості соняшникового ізоляту в плавленому сирі $\epsilon$ органолептична оцінка розробленого продукту (рис. 1).

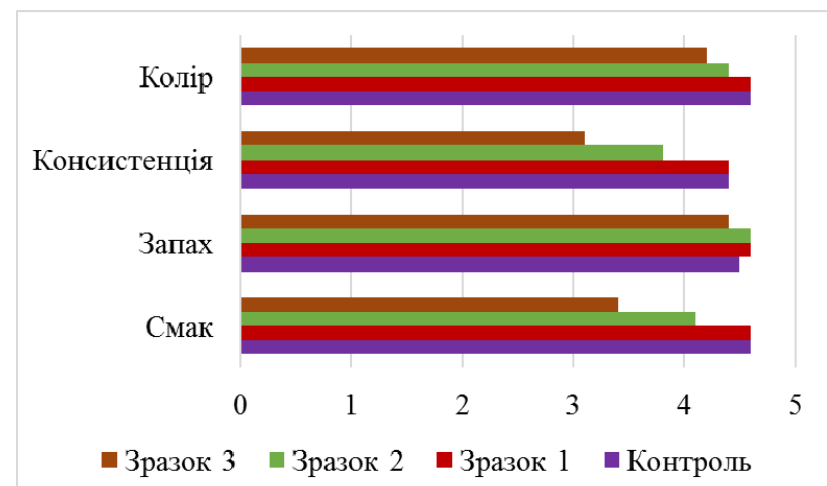

Рис. 1. Органолептична оцінка досліджуваних зразків, бал

Аналізуючи отримані результати слід зазначити, що органолептичні показники контрольного та першого зразків були оцінені в однакову кількість балів. Лише за показником запаху у першого зразка значення на одну десяту бали вище. Зразки два та три в результаті дегустаційної оцінки за смаком поступилися першим двом на 0,2 та 0,4 бали відповідно. Запах третього зразка із відсотком соняшникового ізоляту $5 \%$ не поступався зразку 1 та був оцінений на 0,1 та 0,2 бали вище ніж у контрольного й третього зразків відповідно. Збільшення відсотку соняшникового ізоляту призвело до погіршення смаку розроблених зразків. Зразок 2 поступився контрольному та першому зразкам на 0,5 балів, а третій - на 1,2. Схожа картина спостерігалася і 3 консистенцією. Другий та третій зразки досліджуваного продукту відповідно поступилися першим двом на 0,6 та 1,3 бали.

Отже, введення у рецептуру плавленого сиру соняшникового ізоляту у кількості 3 \% дозволило отримати, за результатами органолептичної оцінки, більш високі результати порівняно з іншими зразками.

Враховуючи отримані результати прийнято рішення подальші дослідження проводити 3 контрольним та першим зразками. Для плавлених сирів важливе значення мають структурно-механічні показники, оскільки безпосередньо впливають на зовнішній ви- гляд, спосіб пакування. Результати експериментальних досліджень представлено в таблиці 1.

Таблиця 1

Структурно-механічні показники $(\mathrm{M} \pm \mathrm{m})$

\begin{tabular}{lcc}
\hline \multicolumn{1}{c}{ Показник } & \multicolumn{2}{c}{ Зразок } \\
\cline { 2 - 3 } & контроль & 1 \\
\hline Зусилля пенетрації, $\mathrm{kN} / \mathrm{m} 2$ & $2,7 \pm 0,17$ & $4,5 \pm 0,12$ \\
Пружність, $\mathrm{kN} / \mathrm{m} 2$ & $6,6 \pm 0,53$ & $7,2 \pm 1,02$ \\
\hline
\end{tabular}

Результати досліджень розроблених зразків плавленого сиру 3 соняшниковим ізолятом дозволяють стверджувати, що введення у рецептуру рослинної добавки підвищувало структурно-механічні властивості. Збільшення показника зусилля пенетрації свідчить про ущільнення консистенції. Відносно контрольного зразка цей показник збільшився на $1,8 \mathrm{kN} / \mathrm{m} 2$. Показник пружності, який характеризує еластичність сирної маси контрольного зразка був нижчий ніж першого на $0,6 \mathrm{kN} / \mathrm{m} 2$. Отримані результати дозволяють зробити висновок, що введення у рецептуру соняшникового ізоляту веде до незначних структурних змін в межах нормативної документації.

В ході дослідження встановили, що контрольний зразок містить 11,36 \% білку, а зразок 1 - 11,55\%. Слід зазначити, що суттєво вміст білку не змінився.

\section{Висновки}

Враховуючи результати описаних досліджень зауважимо, що розроблений плавлений сир $33 \%$ соняшникового ізоляту відповідає вимогам нормативної документації за органолептичними та структурно-механічними показниками. Структурномеханічні характеристики першого зразку вказують на те, що введення у рецептуру рослинної добавки позитивно впливає на зусилля пенетрації та пружність. Однак, введення трьох відсотків соняшникового ізоляту не вплинули на вміст у продукті білку.

\section{References}

Alexandrino, T. D., Ferrari, R. A., de Oliveira, L. M., Ormenese, R. C. S. C., \& Pacheco, M. T. B. (2017). Fractioning of the sunflower flour components: Physical, chemical and nutritional evaluation of the fractions. LWT, 84, 426-432. doi: 10.1016/j.lwt.2017.05.062.

Awad, R. A., Salama, W. M., \& Farahat, A. M. (2014). Eff ect of lupine as cheese base substitution on technological and nutritional properties of processed cheese analogue. Acta Sci. Pol., Technol. Aliment, 13(1), 55-64. doi: 10.17306/j.afs.2014.1.5.

Bolhova, N., \& Krevsun, K. (2019). Vykorystannia ekstraktu lystia voloskoho horikha $\mathrm{v}$ tekhnolohii plavlenykh syriv. Tekhnichni nauky ta tekhnolohii, 3(17), 219-226. doi: 10.25140/2411-5363-20193(17)-219-225 (in Ukrainian).

Carić, M., \& Kaláb, M. (1993). Processed Cheese Products. Cheese: Chemistry, Physics and 
Microbiology, Springer, Boston, 467-505. doi: 10.1007/978-1-4615-2648-3_15.

Dabbour, M., He, R., Ma, H., \& Musa, A. (2018). Optimization of ultrasound assisted extraction of protein from sunflower meal and its physicochemical and functional properties. J Food Process Eng, e12799. doi: 10.1111/ jfpe.12799.

DSTU 5038:2008 (2009). Syry. Vyznachennia vmistu azotu metodom Kieldalia. Kyiv (in Ukrainian).

El-Neshawy, A. A., Farahat, S. M., \& Wahbah, H. A. (1988). Production of processed cheese food enriched with vegetable and whey proteins. Food Chemistry, 28(4), 245-255. doi: 10.1016/0308-8146(88)90100-8.

El-Sayed, M. M. (2006). Use of plant protein isolates in processed cheese. Molecular Nytrition. Food Research, 41(2), 91-95. doi: 10.1002/food.19970410207.

González-Pérez, S., \& Vereijken, J. M. (2007). Sunflower proteins: overview of their physicochemical, structural and functional properties. J. Sci. Food Agr, 87(12), 2173-2191. doi: 10.1002/jsfa.2971.

Horalchuk, A. (2006). Rheological methods of raw foods and automation of payments rheological characteristics. doi: 10.13140/RG.2.1.2739.7847 (in Ukrainian).

Ivanova, P., Chalova, V., Kalaydzhiev, H., PerifanovaNemska, M., Rustad, T., \& Koleva, L., (2017). PepsinAssisted Transglutaminase Modification of Functional Properties of a Protein Isolate Obtained from Industrial
Sunflower Meal. Food technology and biotechnology, 55(3), 420-428. doi: 10.17113/ftb.55.03.17.5061.

Pedroche, J. (2015). Utilization of Sunflower Proteins. Sunflower Chemistry, Production, Processing, and Utilization, 395-439. doi: 10.1016/B978-1-89399794-3.50019-2.

Ren, J., Sun, X. H., Lin, G. P., Zheng, X. Q., \& Liu, X. L. (2012) Isolation and Characterization of Sunflower Protein Isolates and Sunflower Globulins. Information Technology and Agricultural Engineering. Advances in Intelligent and Soft Computing, 134, 441-449. doi: 10.1007/978-3-642-27537-1_54.

Salgado, P. R., Molina Ortiz, S.E., Petruccelli, S., \& Mauri, A. (2011). Sunflower Protein Concentrates and Isolates Prepared from Oil Cakes Have High Water Solubility and Antioxidant Capacity. J Am Oil Chem Soc, 88, 351-360. doi: 10.1007/s11746-010-1673-z.

Shchekoldina, T. V., \& Aider, M. (2012). Production of low chlorogenic and caffeic acid containing sunflower meal protein isolate and its use in functional wheat bread marking. Journal of Food Science and Technology, 51(10), 2331-2343. doi: 10.1007/s13197012-0780-2.

Talbot-Walsh, G., Kannar, D., \& Selomulya C. (2018). A review on technological parameters and recent advances in the fortification of processed cheese. Trends in Food Science \& Technology, 193-202. doi: 10.1016/j.tifs.2018.09.023. 